\title{
痛みに対する非破壊的経皮電気刺激療法の臨床経験
}

\author{
黒田良太郎・田口葶・赤井 文治・渡部優 \\ 井奥 匡彦・越野兼太郎*・最上平太郎*・金井 信博**
}

\section{Clinical Experiences of Non-destructive Transcutaneous Afferent Electrical Stimulation Therapy for Pain Relief}

\author{
Ryotaro Kuroda, Kaoru Taguchi, Fumiharu Akai, Masaru Watanabe, \\ Masahiko Ioku, Kentaro Koshino*, Heitaro Mogami* \\ and Nobuhiro Kanai** \\ Department of Neurosurgery, Kinki University \\ * Department of Neurosurgery, Osaka University \\ **Department of Neurosurgery, Toyonaka City Hospital
}

\begin{abstract}
Summary
Clinical experiences of the transcutaneous afferent electrical stimulation therapy for various types of intractable pain are reported. A total of 29 pain patients included 9 residual or recurrent chronic pain patients who had had various destructive pain treatment, 15 non-malignant chronic pain patients and 5 patients with pain duc to malignant tumors. In $93 \%$ of the patients complete or partial relief of pain was observed. After the subsequent successive stimulation therapy from a week to two years and ten months $86 \%$ of the 22 patients who could use the stimulator by themselves in free of charge got pain relief in more or less degree. Only $42 \%$ of these patients, however, wished to continue this therapy for their pain relief. All the malignant tumor patients and many posttraumatic chronic headache patients with Barré-Lieou syndrome discontinued electrical stimulation. Good benefits are to be expected from this non-destructive treatment for chronic pain in combination with medication and/or destructive treatment.
\end{abstract}

Key words: gate control theory, non-destructive pain relief, transcutaneous electrical stimulation

\section{1 はじめに}

癌末期頑痛や各種の治療に抗する慢性の痛みに対し て，末梢神释より中枢神経采にいたる痛敩伝導路の各高 さに扮ける外科的遮断が行われてきた。しかしいわる 痛覚伝導路も，春䯠・脳幹・視床・大㨫と上行するにつ れ divergent なひろがりを示し(31213314)，どの部位の遮 断でも永久的に除痛しうる理想的な手術標的恃見出しが たい.
一方, 痛みの機構については従来より specificity the一 ory p pattern theory が唱えられていたが, 臨床的事実 との間に矛盾も多く，両者の合成とも考兄られる gate control theory $x^{\circ}$ Melzack and Wall'20)に上り提唱され た.これ以後痛みの外科も従来の destructive treatment に加立て, gate control system $の$ neuromodulation を応 用した電気刺激による痛みの抑制一鎮痛とい5 nondestructive treatment の開発研究が盛んになり, 慢性電極

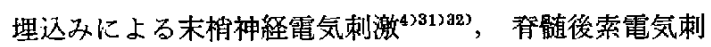

近畿大学脑神経外科

*大阪大学媨神释外科

**市立豊中病院檤神経外科

[連絡先: $\bar{T} 589$ 大阪府南河内郡狭山町西山 380 , 近畿大学脳神経外科, 黑田良太郎]

1978年 5 月 30 日 受稿 


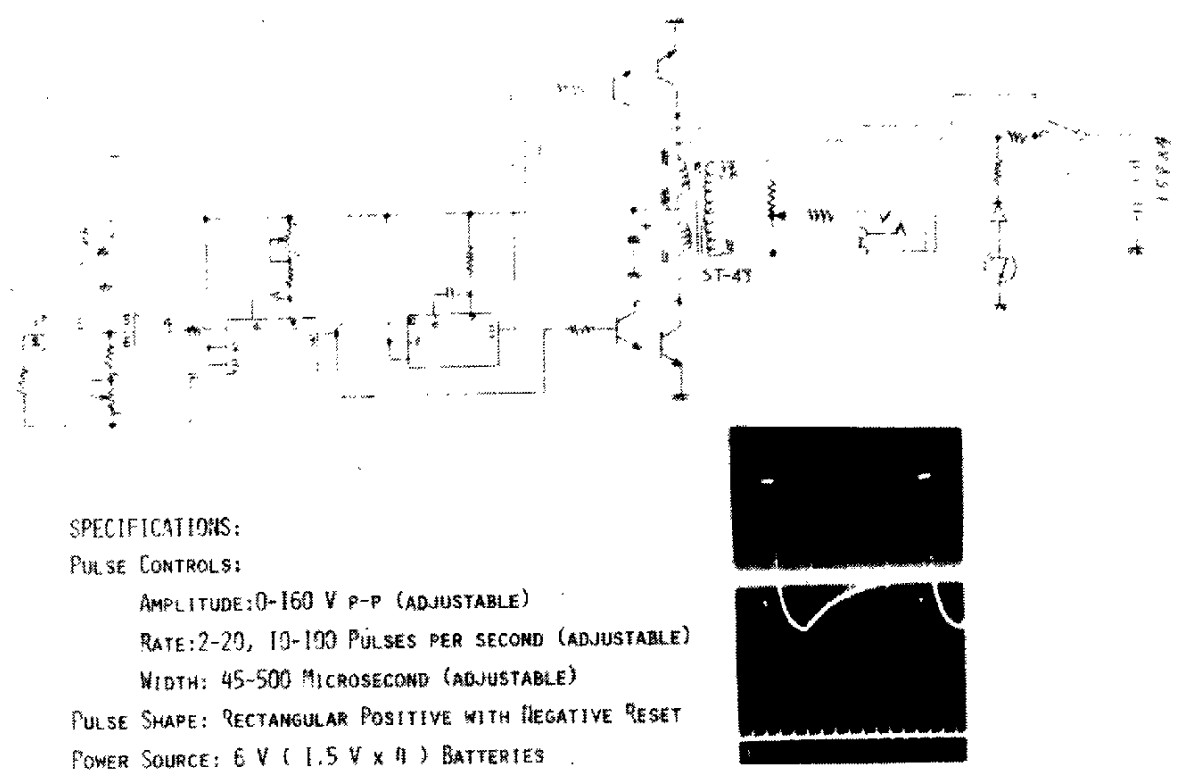

Fig. I The block-diagram, specification and generated wave pattern of personal stimulator S6163A (Nihon Koden Kogyo Co.).

激 ${ }^{23283}$ が, アメリカのペースメーカー器機の進步ととも に実用段階に入ってきた。

しかし埋込み電極による合併症も報告されるよらにな り，また電極埋込みの效果予測と適応決定のスクリー二 ングとして試双られた表面電極による経皮的電気刺激 (transcutaneous electrical stimulation, external electrical stimulationぬたは cutaneous afferent stimulation と もい5. 以下 T.E.S.と省略する.)功予想外に鎮痛効果 を示し，以後り理迈み党必要としない患者が相当数ある ことがわかりり ${ }^{17)}$ ，以わ後索刺激療法の副産物として T.E.S.が注目されるよらになった。本法注刺激笗了後 の効果持続が短いため，患者自身が手軽に利用できる小 型携査用の安定した personal stimulator を必要とする. アメリカでは各種の personal stimulator が利用でき，本 療法の普及に貢献しているが，本邦ではパラメーターの そしい低周波刺激装置しかなかった。このため，日本光 電工業と personal stimulator, S6163A t共同試作し, 1975年以来わたくしどもも除痛手術後の再発痛, 遗残 痛, 外賃後の慢性痛，その他外科的除痛手術適応にいた らぬ慢性痛, 曒末期疼痛などに対して，皮膚表面電極に よるT.E.S.を試孤てるので，若干の臨床治験を報告 し, 痛みの外科に和ける適応，今後の問題点などを考察 したい.

\section{II 刺激方法と効果}

放たくしどもの使用した stimulator S6163A は Fig. 1 のよ5な短形波パルス発生，6Vのバッテリーで，パ ルス振幅 $0 \sim 160 \mathrm{~V}$, 顧度 $2 \sim 20$, または 10〜100/秒の 2 種類, パルス幅 $45 \sim 500 \mu \mathrm{sec}$, 各パラメーターは可変 である，電極は現在のところ心電図用の使い唅て平血電 極を使用している。刺激部位は，痛み領城内の圧痛点や 痛み項域支配神経刺激点——頭部 - 顔面では後頭神経, 眼曧上神経, 眼窝下゙神経, その他こめかみ，耳孔前，口 角などである。大後䫒神経在痛点は有髪部位であるので 少し下方にすらす，身邀上肢では腕神程叢，肋間神経， 尺骨・暁骨神経など, 背部では傍脊椎部, 下肢では大艆 神経, 脛骨・腓骨神経などの刺激点に陽極電極をはりつ

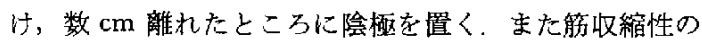
痛みではそれぞれの筋一笳膜におりる trigger point $\mathrm{t}^{21}$ 老刺激点に選ぶこともあり，一般的には局所麻酔して友 て鎮痛の得られる点の電気刺激が有効の上らである，

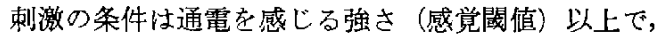
かつ電気的痛み（疼痛闘值）を感じない强さに設定，刺 激瀕度，パルス幅は各患者が快適と感じるパラメーター を選ばせるが，一般に20 Hz 以下の低嚬度，パルス幅は $こ の$ stimulator 最大の500 $\mu \mathrm{sec}$. 好好人が多い. 刺激效 果は電流量できまるが，皮膚のインピーダンスは一定で 
Table 1 Pain suppressive effect of transcutaneous stimulation for various painful conditions and patient's wish whether to continue stimulation therapy or not after self-stimulation period are summarized.

Trigeminal Neuralgia

\begin{tabular}{|c|c|c|c|c|c|c|c|c|}
\hline Patient & Age Sex & Etiology & Painful Sites & $\begin{array}{l}\text { Pain } \\
\text { Relief of } \\
\text { Local } \\
\text { Block }\end{array}$ & $\begin{array}{l}\text { Pain } \\
\text { Suppression } \\
\text { on Test } \\
\text { Stimulation }\end{array}$ & \multicolumn{2}{|c|}{$\begin{array}{l}\text { Pain Suppression } \\
\text { on Subsequent } \\
\text { Stimulation }\end{array}$} & \multirow{2}{*}{$\begin{array}{l}\text { Wish to } \\
\text { Continue } \\
\text { Stimulation }\end{array}$} \\
\hline 1. S.T.* & $65 \mathrm{~F}$. & Herpes & $\begin{array}{l}\text { Supraorbital } \\
\text { Temple }\end{array}$ & + & + & & $+(4 w)$. & \\
\hline 2. S.N.* & $70 \mathrm{~F}$. & $\begin{array}{l}\text { Postrhizotomy } \\
\text { herpes }\end{array}$ & $\begin{array}{l}\text { Maxillary } \\
\text { Occipital }\end{array}$ & + & + & Partial & $+(6 \mathbf{M})$. & died \\
\hline 3. Y.K. & $68 \mathrm{~F}$. & & Mandibular & & + & & & \\
\hline 4. H.Y. & 65 F. & Herpes & $\begin{array}{l}\text { Supraorbital } \\
\text { Parietal }\end{array}$ & + & + & & & \\
\hline 5. H.K.* & $53 \mathrm{~F}$. & $\begin{array}{l}\text { Residual pain } \\
\text { after alcohol block }\end{array}$ & $\begin{array}{l}\text { Lip. tongue } \\
\text { Occipital. } \\
\text { nucha, }\end{array}$ & + & + & Partial & $+(10 \mathrm{M})$. & + \\
\hline 6. K.S.* & $43 \mathrm{~F}$. & $\begin{array}{l}\text { Residual pain after } \\
\text { removal of } \\
\text { trigeminal } \\
\text { neurinoma }\end{array}$ & $\begin{array}{l}\text { Deep part of } \\
\text { check, temple }\end{array}$ & & + & & $+(4 w)$. & + \\
\hline
\end{tabular}

Trigeminal Dysesthesia

1. M.O. $38 \mathrm{M} . \quad \begin{aligned} & \text { Maxillary } \\ & \text { fracture }\end{aligned} \quad \begin{aligned} & \text { Maxillary } \\ & \text { Temple }\end{aligned}$ 土 Partial+ $\quad$ Partial+(10M.)

Glossopharyngeal Neuralgia

1. M.N.* $66 \mathrm{M} . \underset{\begin{array}{r}\text { Residual pain } \\ \text { after alcohol block }\end{array}}{\begin{array}{l}\text { Neck, Jaw, } \\ \text { Throat }\end{array}}++\quad+\quad+(4 \mathrm{M})+$.

* Ablative pain treatment has previously been performed.

なく，同一部位でも時間の経過とともに皮膚の状態によ り変わりうるので, 感覚閥值をこえる程度の蚛さと説明 する方が患者には実際的である，感覚閶值より刺激の強 さを上げていくと，疼痛閶值までの間に筋収縮をおこす 強さがある，患者によってはこの低頻度の筋収繀をむし ろ快適とするものもあり，必ずしも筋収縮閾值以下でな ければならぬことはない。

刺激療法の実際は外来または病棟で，上述の刺激点を パラメーターを変えてテスト刺激を行い, 痛加の消失，

軽快を得る患者に personal stimulator 貸し出し，患者 自身に刺激を行わせている。この際，心疾患患者や心蔽 ペースメーカー埋込患者，妊婦八の使用は避ける。患者 の中には以前低周波療法至受计たものがあり，低周波療 法と受取るものもあるが， gate control theory の説明， stimulator の使用法などを十分説明して貸し出した。刺 激時閒は 1 回 $1 \sim 2$ 時間，1 日数回と指示しているが， 睡服直前まで日中ずっと刺激を続けるるのもあり，特に 副作用は認められていない，刺激教果は刺激点を中心に ピリピリする感し，振動感などが痛み領域に快適にひろ がり，痛みのたか不眠を訴える患者が病院外来で刺激開
始後数分で寝込むことすしばしば見られる，交た逆に頭 顠部外傷後の Barré-Lieou 症候群患者の中に, 電気刺激 により頭涌増覀, 冷汗などを示すむのもあった。

鎮痛のひろがりに関しては，刺激神経支配領域（pri一 mary effect）以外に，たとえば顔面痛の場合，三实神経 領域以外に後頭部の痛みも軽快することがよく認められ る (remote effect).

刺激後の後効果については一般に長くなく，長く継続 刺激を続けている人では終了後すぐもとの状態にもじる といら人が多い，しかしなかには，激痛発作の起こりそ うな前兆の釯痛を感じた時（たとえば偏頭痛），十分刺激 を行えば痛みが消失してしまらこともある。

効果判定时患者自身の評価で，痛み消失，多少痛办軽 堿，無勃の3 段階である．継続使用は最長 2 年10力月， 最短 1 週間であるが，今後とむこの刺激療法を続ける希 望の有無についても調査した。

\section{I 治 験}

現在までのところ治験症例は Table 1，2，3のごとく 29例である。疾㭧別に見る上，三多神経痛群は Table 1 


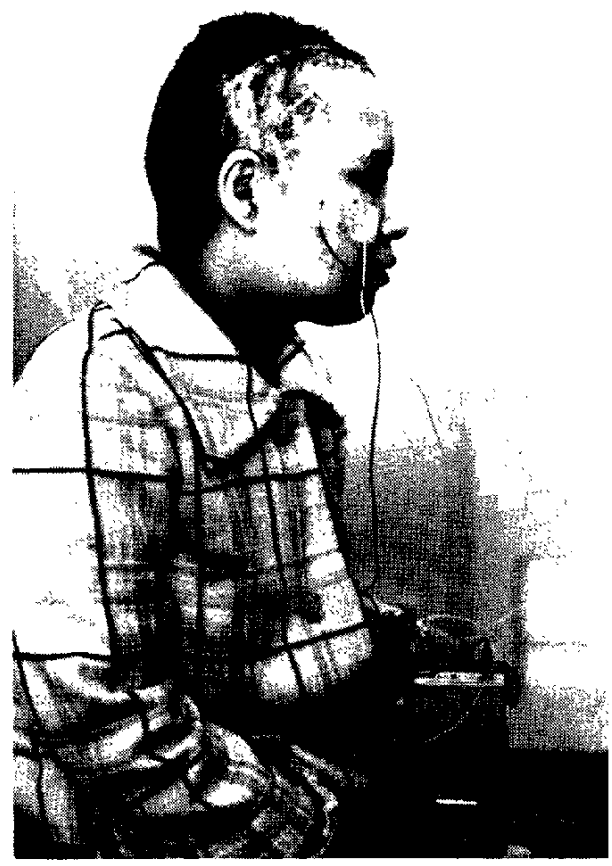

Fig. 2 This depicts the scene in which a patient with residual facial pain after partial removal of trigeminal neurinoma is making transcutaneous stimulation on the infraorbital nerve.

のごとく，帯状ヘルペス後，半月神経節アルコールブロ ック後, 節後神経根切断術後, 半月神释節神経鞘腫部分 摘後などの遺残痛，再発痛患者と上䫑骨骨折による第 2 枝領域の異常感覚と鈍痛の7 症例で，局麻ブロック有効 例法同部のテスト刺激でも鎮痛を得る。このうち継続刺 激を行ったもの5例でいずれも一応の効果は認るてい ๖.

Fig. 2 は著効を示した症例 6 K.S. である.三神経 鞘腫部分摘後の遗残痛に T.E.S. 在行っている状態を示 寸もので，本患者注三攴神程痛を訴えて来院，検查の結 果三叉神経鞘腫と判明したものである．現在刺激4週間 目に入っている. 症例 $1 \mathrm{~S} . \mathrm{T}$. は9年来のへルペス後三 叉神経捅で，以前に眼窩上神経局麻ブロック，アルコー ルブロック，バイブレーターによる機械的刺激，半月神 経節定位的りニアック多門照射，眼窝上神経切断術など を受け，漸次灼熱痛は軽快しつつあるが，な和前額・側 頭部の痛みは残っている，眼窩上神経電気刺激で著効を 見ていたが漸次後效果の持続が短くなり，最近では，刺 激中は快適であるが終了直後かえってカッカとする痛み ありとのことで電気刺激中止した。

症例 2 S. N. は三叉神経痛のため節後神経根切断術 を受けたが術後すぐ anesthesia dolorosa 様の痛みを訴
え，また術後経過中へルペスに霍患したといらことで来 院.一側性 cingulumotomyで一店痛みは自制可能となり 退院したが，な拉痛みは残る．以後自宅で T.E.S.療法 を6力月継続，多少上す軽快を見ていたが死亡した。

症例 5 Fi.K. 江第 3 枝 $の$ 三攴神释痛で過去 3 度半月 節フルコールブロックを受けたが，な和歯槽・舌の一部 に遗残痛あり，提食・会話困難が見られる，口角，外耳 孔前方顔面などの刺激で，「刺激中のみ電気が走って多 少痛み軽快」とのことで T.E.S.10力月継続中である. 結局この群で沬継続使用者 5 例, 1 例死亡, 今後もT.E.S. 続行希望は 2 例であった。

舌咽神程痛の症例 1 M.N. は咽頭加ら下顎・耳介部 に加けて激痛発作あり，上喉頭神経の局所ブロックで発 作減少，持続痛む軽快しつつあったが，なお咽頭・下䫈 部の鈍痛を訴える．同側胸鎖乳突筋内粶部に圧痛点を認 めたのでここの部の T.E.S.を行ったところ非常に快適 で痛み交忘れるとのことで，4力月間自宅で T.E.S.を 続行し，持続性鈍痛消失，激痛発作すほとんど起こらな くなった

いうゆる頭頸部外傷後遺症の慢性頭痛患者は Table 2 のごとく9例で，明らかに神経症的な訴えをすつ症例 6 を除くと，全例後頭・後頸部に压痛点を有し，局所ブロ シク有效, 同部のテスト刺激でも有效であった。この5 ち症例 1，3，5 はそれぞれ大後頭神释の電気凝固術を受 けているが，頑痛がつらくものである。

症例 8 S.K. トラック荤転手. 前方交通事故のた め，高速道路上で停車したところへ大型トラックに追突 され，救急病院 2 力月入院後来院した，後頭・項部痛つ よく，著しい平衡失調がある，大小後頭神経・胸銧乳突 筋に強い在痛があり，この点の電気刺激で直後より頭痛 消失，項部や厓のこりもとれ，頙が軽くなるといら，夜 就寝前に T.E.S. 在行5とよく眠れるよ5になる。現在 6 力月使用中であるが効果恃続している，頭頸部外傷 後遗症で T.E.S.の継続を行ったものは前記症例を含め 5 例であるが，今後もT.E.S. 索続ける希望者は 1 名の みである。他症例は 2 调間の stimulator 試用期間中は一 応効果を見ているが，十分の鎮痛は得られない，突然効 果がなくなったなどにより脱落.

症例 7 K. M. 追突事故後の鞭打症患者で頭痛以 外にも，めまい，暗点，視力障害など多彩な愁訴を有 し，刺激とともに，冷汗，めまい悪化，頭痛はかえって ひどくなるとのことで脱落した，嘔気，めまいなど自律 神経症状の強い場合，T.E.S. 愔適当でない印象を受け t.

筋䗟張性頭痛の症例 H. T. は, 先天性の頸笳異常肥 
Table 2 Pain suppressive effect of transcutaneous stimulation for various painful conditions and patient's wish whether to continue stimulation therapy or not after self-stimulation period are summarized.

Posttraumatic Head \& Neck Pain

\begin{tabular}{|c|c|c|c|c|c|c|c|}
\hline Patient & Age & Sex & Painful Sites & $\begin{array}{c}\text { Pain Relief } \\
\text { of Local } \\
\text { Block }\end{array}$ & $\begin{array}{l}\text { Pain Suppres- } \\
\text { sion on Test } \\
\text { Stimulation }\end{array}$ & $\begin{array}{l}\text { Pain Suppression on } \\
\text { Subsequent } \\
\text { Stimulation }\end{array}$ & $\begin{array}{l}\text { Wish to } \\
\text { Continue } \\
\text { Stimulation }\end{array}$ \\
\hline 1. T.M.* & 44 & M. & $\begin{array}{l}\text { Occipitotemporal, } \\
\text { nucha }\end{array}$ & + & + & $+(2 w)$ & - \\
\hline 2. K.H. & 49 & M. & $\begin{array}{l}\text { Occipitotemporal } \\
\text { (Nausea) }\end{array}$ & + & + & Partial $+(2 w)$ & \\
\hline 3. Y.E.* & 43 & F. & $\begin{array}{l}\text { Occipitotemporal } \\
\text { (Nausea, Vertigo) }\end{array}$ & + & + & $+(2 w) \rightarrow-$ & - \\
\hline 4. H.Y. & 60 & M. & $\begin{array}{l}\text { Occipitotemporal } \\
\text { (Vertigo) }\end{array}$ & + & + & & \\
\hline 5. M.Y.* & 62 & M. & Occipitotemporal & + & + & & \\
\hline 6. K.O. & 31 & M. & Frontal (PN) & - & - & & \\
\hline 7. K.M. & 35 & M. & $\begin{array}{l}\text { Occipitonuchal } \\
\text { (Vertigo, Scotoma) }\end{array}$ & + & + & $-(1 w)$ & - \\
\hline 8. S.K. & 41 & M. & $\begin{array}{l}\text { Occipitonuchal } \\
\text { (Vertigo, Ataxia) }\end{array}$ & + & + & $+(6 \mathrm{~m})$ & + \\
\hline 9. Y.K. & 28 & M. & Occipitonuchal & + & + & & \\
\hline \multicolumn{8}{|c|}{ Muscle Contraction Headache } \\
\hline 1. H.T. & 32 & M. & $\begin{array}{l}\text { Occipitonuchal } \\
\text { Temple }\end{array}$ & + & + & $+(1 w)$ & - \\
\hline \multicolumn{8}{|c|}{ Spastic Neck Pain after Stroke } \\
\hline 1. K.K. & 32 & M. & Neck & + & + & $-1(3 w)$ & + \\
\hline
\end{tabular}

* Ablative pain treatment has previously been performed.

大，頸肋があり 2 度手術を受けている，肥大した一側胸 鎖乳突筇のため後頭・項部括よひ側頭部に慢性頭痛あ り，10数年間鎮痛剂在漸用してきた。䇟電図検查では at rest ですでに Fig. 3 のごとく肥大側に执いて 異常放 電を認少。，同筋在䄪15分 T.E.S. 施行し直後の筋電図 を見ると, 刺激前に比し著明に異常放電が減少している のが認められ，頭痛号軽減した。本患者は 1 週間 stimulator 使用後, 鎮痛㓮の方が効果持続が長いからとい5 理由で T.E.S. を拒否した。

高血圧性脳内血腫除去術後の症例 K.K. 汇術後も片 麻㾝改善せず，リハビリテーションを受けているが，麻

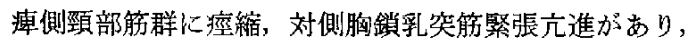
頸は麻瘏側を向いたままで正面，対側への迴転は不能で あった. 対側胸鎖乳突筋圧痛点への電気刺激を行ったと ころ备転時の痛みが減少し，T.E.S. 続行約 3 週間で漸 欧頸部㛠転も容易となった。

偏頭痛（Table 3) 患者は 2 例であるが, いずれも長年 にわたる発作で大量の鎮痛剤を連用してきた。

症例 1 S. M. 看護婦。偏頭痛発作以外にも慢性的 に後頭痛・肩凝りがあり, 発作の前兆としてこの亜化が
見られる。後頭神経への低頻度電気刺激は, 後頭痛, 屃 凝りを軽快させ，勱務中も前兆を感じると T.E.S.を開 始している. 偏頭痛発作回数も減少し，I年使用後むな お継統希望である。ただし激痛発作が一旦起こると，

T.E.S.では効果は見られないといら。

症例 2 F.T. . 偏頭痛発作 と, 同側眼窝上部・こめ かみに持続性鈍痛あり。この痛みが六進すると睑を開け ておれなくなり，発作が始まることが多い，眼窝上神経， こかかみに压痛点があり，この点の T.E.S.で開眼可能 となり, 持続痛は軽快する.Fig. 4 は本患者の昨年 2 月 に招ける偏頭痛発作の出現状洗と T.E.S.の効果を示 し, 表中の小表で 3 力月間に㕲ける発作回数と T.E.S. 効果を示している. 激しい発作時では鎮痛効果汢認めが たいが，軽い発作で注鎮痛效果と発作時間短縮が見られ る. 小表中でも激しい発作で忧約半数のみに多少效果が 見られるに反し，軽い発作ではほぼ全発作に鎮痛效果が 見られるといら．ただし激しい発作時に T.E.S. を始め る余裕はなく，発作後半になってから刺激を開始すると い5. 本症例もなお T.E.S. 続行中である.

腰椎椎間板へルニア術後療着性クモ膜㭥 (Table 3) 


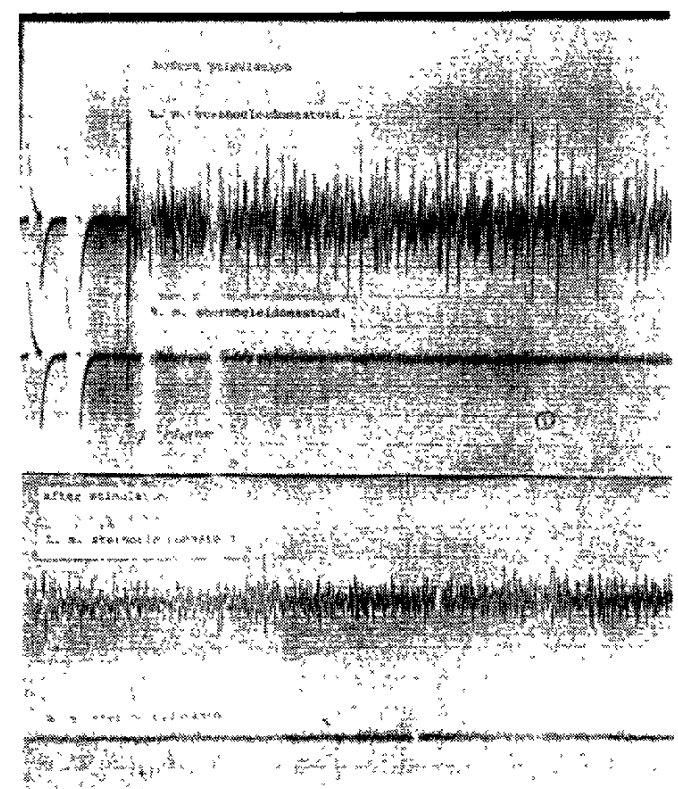

Fig. 3 This figure shows the improvernent of EMG after transcutaneous stimulation on the hypertrophed sternocleidomastoid muscle in a patient with chronic muscle contraction headache. The upper two tracings show EMG of left (hypertrophied) and right muscle at rest, respectively, before stimulation. Spontancous abnormal discharges in the left muscle decreased after stimulation as seen in the lower two tracings. The upper EMG of the lower two tracings: left muscle, the lowest: right muscle

症例 1 K. T. は 2 度の燎着剝離術を受けたが，両下肢・ 腰背部のジンジンするような持続痛あり，下部胸䯚位以 下に感覚种麻, 腰仙髄位レベルでは pin-prick 脱失, 排 尿困難があった，一側性 cingulumotomyで約 3 力月鎮痛 を得たが，再び痛みの訴え出現し，以来約 2 年間, 傍脊 柱部・腰部・下肢の压痛点局麻ブロックを続けた. 原因 不明の微熱が出現するので，局麻ブロックに替えて压痛 点に電気刺激を加えたところ䛔み軽娍を認ぬた。これが personal stimulator $\$ 6163 \mathrm{~A}$ の開発を促した。この患者で 圧痛点の一つである L. Gluteal nerve $30 \mathrm{~Hz}$, 感覚 閾値の強さで約15分電気刺激を行い，その前後でL tibial nerve 刺激による知覚誘発電位を比較したところ, 刺激後の primary response 振幅娍少を認めた (Fig. 5). 以後 2 年 10 力月 T.E.S. 続けて一応の鎮痛効果を見て

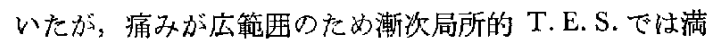

足できなくなり，手術を強く望むようになった，前回手 術の対側 cingulumotomy施行，数日後より痛み消失し， 再手術後 6 力月を経過しているが，特に鎮痛剤投与もな く, 自制できる程度の軽い痛みの訴えは時に見られる が，自宅でのT.E.S.で十分痛みのコントロール可能と なった

嘠炎後の四肢固縮症例 K.Y.はリ八ビリテーション の過程で特に一側肩・上肢の痛みを訴えたが、棘上・棘 下笳・三角筋などの圧痛点への T.E.S. をリハビリテー ションと併行し，十分リハビリテーションの効果を上げ ることができた。

恶性腫瘍患者への T. E. S. は 5 例で試みられた。

症例 $1 \mathrm{~K} . \mathrm{O}$. 㳊後腹膜腫瘍で一側腰・下肢激痛を訴 えた．腰部への T. E.S. で多少は痛みもまぎれるとのこ とで鎮痛剈上の併用で 1 週間経過を観察したが，患者の 満足は得られなくなった。経皮的コルドトミーで完全除 痛を得た。

症例 2 K. K. は電気工学の大学教授であるが，舌癌 再発と顎下リンパ節転移のため，頸部広範廓清術とリニ アック照射を受けた 同側顔面，側頭部の不快な鈍痛を その後も訴えていた，眼窩上神経，こかか力の圧痛点な との T.E.S.テスト刺激で十分鎮痛效果を見たので 2 週 間 T.E.S.に熱中せしめたところ，痛みは楽になるがだ んだん感覚闇值が上がって心配だとの理由で stimulator を返却，鎮痛剤注射を望んだ，他の 3 例多一時的には T.E.S. で頡痛効果充見るが，症状悪化とともに痛みも 広範囲，激烈となり pain-modulation 程度では满足でき なくなった。

以上の治験を Table 4 にまとめると，T.E.S. 施行患 者29名中テスト刺激では各疾患を通じ一応の效果を見る るの $93 \%$ でたしかに一時的には鎮痛效果を認める。 Stimulatorの台数に制限がありこのうち stimulator 貸し出して患者自身で随時 T.E.S. を行わせたもの22例 であるが，著効より多少とむ效ありを有効とすると継続 使用者の $86 \%$ に効果を見る，ところが通電中は痛みを忘 れるが後効果が短い，かえって後の痛みがつらい，痛み が激しくてこの程度の modulation では满足できないな どの理由により脱落するものがあり, 今後も T.E.S.を 続けたいとする人忙 $42 \%$ に減少した，この脱落者は疾患 別症例が少ないので結論できないが，頭頸部外傷後遺症 の慢性頭痛患者; 覀性腫癔末期疼痛に多く見られる。悪 性腫瑒末期患者 5 名を除くと, T. E. S. 療法を続けたい とする慢性痛患者は14名中 8 名となり，継続使用者のう ち死亡などを除いて $57 \%$ となった。 
Table 3 Pain suppressive effect of transcutaneous stimulation for various painful conditions and patient's wish whether to continue stimulation therapy or not after self-stimulation period are summarized.

Migraine

\begin{tabular}{|c|c|c|c|c|c|c|c|}
\hline Patient & Age & Sex & Painful Sites & $\begin{array}{l}\text { Pain Relief } \\
\text { of Local } \\
\text { Block }\end{array}$ & $\begin{array}{l}\text { Pain Suppression } \\
\text { on Test } \\
\text { Stimulation }\end{array}$ & $\begin{array}{l}\text { Pain Suppression } \\
\text { on Subsequent } \\
\text { Stimulation }\end{array}$ & $\begin{array}{l}\text { Wish to } \\
\text { Continue } \\
\text { Stimulation }\end{array}$ \\
\hline 1. S.M. & 44 & F. & $\begin{array}{l}\text { R. Head, Nucha } \\
\text { (Nausea, Vomiting) }\end{array}$ & + & + & \multicolumn{2}{|l|}{ Incomplete $+(1 y)}$. \\
\hline 2. F.T. & 35 & F. & $\begin{array}{l}\text { L. Head, Eye } \\
\text { (Nausea, Vomiting) }\end{array}$ & + & + & \multicolumn{2}{|l|}{ Incomplete + (1y.) } \\
\hline \multicolumn{8}{|c|}{$\begin{array}{l}\text { Spinal Arachnoid-Adhesion } \\
\text { Post-Disc Surgery }\end{array}$} \\
\hline 1. K.T.* & 37 & & $\begin{array}{l}\text { Low Back, Hip } \\
\text { Lower Extremities }\end{array}$ & + & + & \multirow{2}{*}{\multicolumn{2}{|c|}{ Partial $+(2 y \cdot 10 \mathrm{~m})+}}$. \\
\hline 2. T.H. & 45 & & $\begin{array}{l}\text { Low Back, } \\
\text { Lower Extremity }\end{array}$ & & - & & \\
\hline \multicolumn{8}{|c|}{ Postencephalitis Rigidity } \\
\hline 1. K.Y. & 50 & M. & $\begin{array}{l}\text { Shoulder, Arm } \\
\text { (Rehabilitation) }\end{array}$ & + & + & $+(3 w)$. & Cured \\
\hline
\end{tabular}

Cancer

\begin{tabular}{|c|c|c|c|c|c|c|}
\hline 1. K.O.** & 33 & M. & $\begin{array}{l}\text { Hip, Lower } \\
\text { Extremity }\end{array}$ & Partial+ & $+(1 w)$. & - \\
\hline 2. K.K. & 52 & M. & Face & + & $+(2 w)$. & - \\
\hline 3. C.O. & 57 & M. & Neck & + & $+(1 \mathrm{~m})$. & - \\
\hline 4. K.S. & 45 & M. & Shoulder, Arm & Partial + & Partial $+(1 w)$. & - \\
\hline 5. S.N. & 42 & F. & Occipital, Nucha & Partial + & Partial $+(2 w)$. & - \\
\hline
\end{tabular}

* Ablative pain treatment has previously been performed.

** Ablative pain treatment has afterwards been performed.

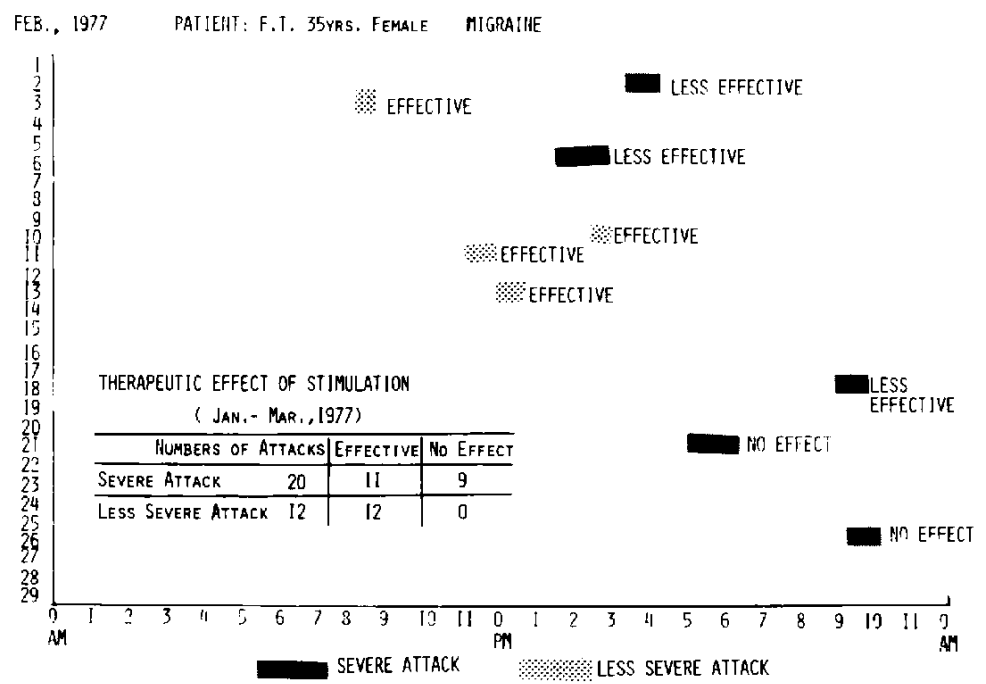

Fig. 4 This figure depicts the frequency of migraine attacks on one patient in February, 1977 and the pain suppressive effect of transcutaneous stimulation on attacks.

abscissa: days in February, ordinate: time in 24 hours. The small table in the left lower corner of this figure shows number of attacks in the period from January to March and the frequency of effective transcutaneous stimulation. 
Table 4 Effect of transcutaneous elcctrical stimulation

\begin{tabular}{lccccc}
\hline & $\begin{array}{c}\text { Number } \\
\text { of } \\
\text { Patients }\end{array}$ & $\begin{array}{c}\text { Pain Relief } \\
\text { of } \\
\text { Local Block }\end{array}$ & $\begin{array}{c}\text { Pain Suppression } \\
\text { on Test } \\
\text { Stimulation }\end{array}$ & $\begin{array}{c}\text { Pain Suppression } \\
\text { on Subsequent } \\
\text { Stimulation }\end{array}$ & $\begin{array}{c}\text { Wish to } \\
\text { Continue } \\
\text { Stimulation }\end{array}$ \\
\hline $\begin{array}{c}\text { Trigeminal Neuralgia } \\
\begin{array}{c}\text { Postherpetic) } \\
\text { Residual }\end{array}\end{array}$ & 6 & $4 / 5$ & $6 / 6$ & $4 / 4$ & $2 / 3$ \\
$\begin{array}{c}\text { Glossopharyngeal Neuralgia } \\
\text { (Residual) }\end{array}$ & 1 & $1 / 1$ & $1 / 1$ & $1 / 1$ & $1 / 1$ \\
$\begin{array}{c}\text { Traumatic Trigeminal } \\
\text { Dysesthesia }\end{array}$ & 1 & $1 / 1$ & $1 / 1$ & $1 / 1$ & $0 / 1$ \\
$\begin{array}{l}\text { Posttraumatic } \\
\text { Head \& Neck Pain }\end{array}$ & 9 & $8 / 9$ & $8 / 9$ & $3 / 5$ & $1 / 4$ \\
$\begin{array}{c}\text { Muscle Contraction } \\
\text { Headache }\end{array}$ & 1 & $1 / 1$ & $1 / 1$ & $1 / 1$ & $0 / 1$ \\
$\begin{array}{l}\text { Migraine } \\
\text { Spinal Arachnoidal } \\
\text { Adhesion }\end{array}$ & 2 & $2 / 2$ & $2 / 2$ & $2 / 2$ & $2 / 2$ \\
Rigido-Spasticity \\
(Rehabilitation)
\end{tabular}

EFFECT ON SEP OF TRAHSCUTAHEOUS ELECTRICAL STIIULATIOOI
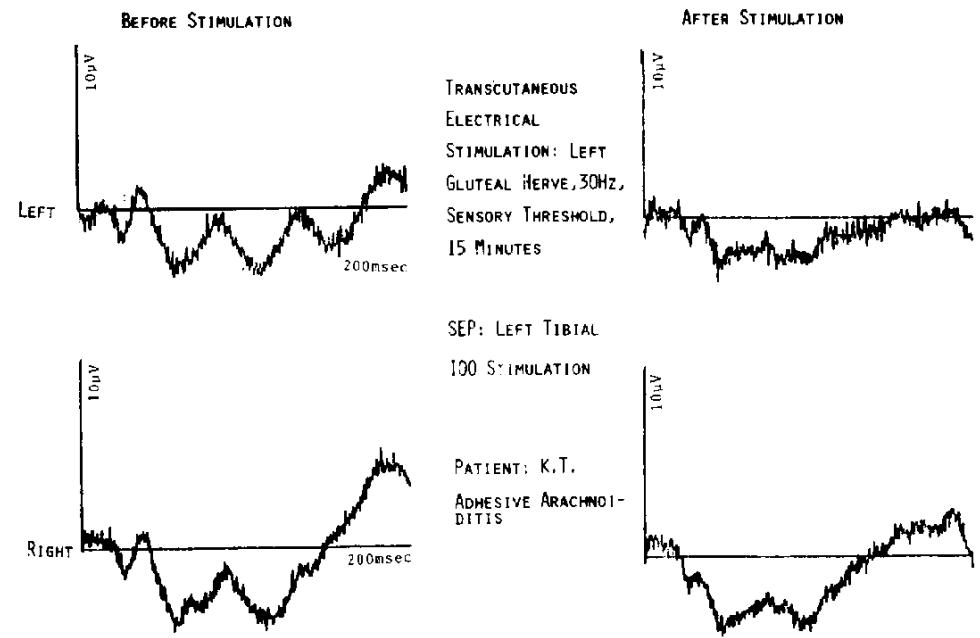

SEP: LEFT TIBIAL

I90 S:IMULATION

PATIENT: K,T.

AdHESIVE ARACHOHOI-

DITIS

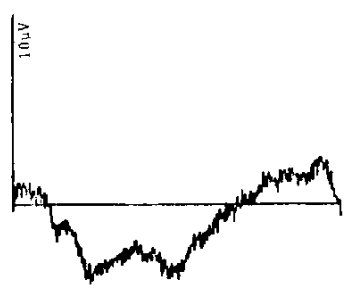

Fig. 5 Cortical sensory evoked potential showed decrease in amplitude of primary response after transcutaneous stimulation in a patient with back and leg pain after disc surgery.

\section{VV 考 察}

せめて痛みだけでも取ってほしいといら悪性腫㩧末期 頑痛に対して各種の㹸神経外科的手術が開発され，余命 期待日数の短い末期痛の除痛は十分その目的を達せられ てきた。しかし痛みの外科にとっての問題は，非要性疾 患や神経系に抢ける各種損稘による慢性の頑痛である。
これに対する手術としては，中枢神経系であれ，末梢神 経であれ不可逆性破壊を行う以上患者の訴え石痛夕を除 き，今後再発することなく，合併症，後遺症を惹起しな いものでなければ積極的に侵襲を扣えることに問題があ る。亦た手術的鎮痛を得ても，再発時さらに再手術を重 小る加否汃は問題である。1965年 Melzack and Wall の提出した gate control 理論は，悩みの多い痛みの外科 
に一つの転機を与えた。すなわち末梢神経太径有㖪線維 の刺激，春髄後索線維の刺激が，春跹後角におりる gate を閉し，細径有鲅・無髄神経線維により伝達される痛み 感敩の中枢一の伝導を㧕制するとい5，非破壊的除痛一 の応用の途を開いた， Gate control 理論そのむのはその 後批判も多く, 彼らは substantia gelatinosa $に$ gate $の$ 存 在想定し, substantia gelatinosa cell $か ら の$ presynaptic inhibition t示唆したが, postsynaptic mechansim も 存在じ，また substantia gelatinosa内の細胞から単一細 胞記録がいまだなされたことがない吕などの事奉があ る. 生春髄後角細胞一の多くの感覚の convergence と その interaction を強調する一方では，七トの epicritic

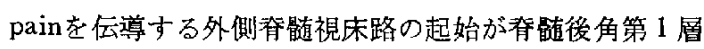
細胞と寸る久留 ${ }^{15)}$ の業績, 後に動物実駼でこれが証明さ れた ことなど無視している. Wall 自身が後に，1965 年の gate control 理諭の論文について言える最大のこ とは，これが多くの批判と実験を促したことであると 述べている33). しかしこの理論以来, 未梢神释電気刺

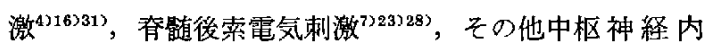
電気刺激1102 などによる除痛法が報告され，複数の gate または抑制系の機構の存在そのものには疑 5 余地はない と思われ者。

慢性電極埋込みによる神経系の電気刺激はその效果を 確実にするものの，埋込みに伴ら合併症を無視するわけ にいかない，春㖪後索への neuropacemaker 埋込みに伴 らさまざをな合併症や患者選択に伴う問題症例柱 600 例 中242例に見られたといら報告》もあり，また本質的に は，神経組織と長期間接触してその周囲に gliosis を伴わ ず電導性も損かない電極材料が存在するかといら問題が ある。

T.E.S.にはこれらの問題がなく，後索刺激のための 電極埋込子患者選択のスクリーニングとして始められた この療法は，またたく間に欧米中心に数多くの経験が重

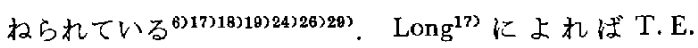
S. の鎮痛効果は placeboでないことは明らかであるが， 臨床生理学的にも皮㲊に与える触覚刺激 ${ }^{83}$, 電気刺激 ${ }^{273}$ が，電気ショックによる痛みの閥值を上げたり, 眼窝下 神経電気刺激が，歯の電気ショックにより誘発される痛 み閑值を上げる22)ことなど明らかにされている。またこ

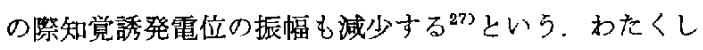
ビもの椎間板ヘルニア術後の腰・下肢痛患者でも, 知覚 誘発電位の振幅減少が観察されている. 筋電図でも, わ たくしどもの muscle contraction headache の症例で, 䫂筋の電気刺激により頭痛軽快, 刺激前異常放電の認め られた箭電図が刺激後放電の減少が認められた。
T.E.S.による鎮痛のメカニズム注在な扔明らかで はない，誘発電位・解電図などの変化は neuromodula・ tion の存在を示すが，これが神経系のどこで起こってい るか結論はでていない上らである，末梢の太径求心線維

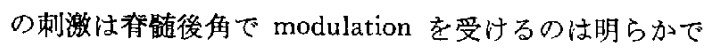
あろうか゚, Melzack and Wallの仮説のように単純でない こと注上述した. 皮盧電気刺激が感覚䦭值以上の強さで は conscious sensation となっているのであるから，脊㖪 を経て脳幹, 視床, 大脳皮質まで達していることは明ら かでありどのレベルに招いても $\mathrm{C}$ 線維由来の痛み刺激 に干涉することは可能であり，また皮質下行線維が視床 感觉特殊核や春髄後角細胞一投射楾維を発していること は明らかで，これが知覚伝详綀胞に干涉し modulation を生じていることありうる、一方末梢神経の直接刺激 は神経線維の blackade を生じることから，T.E.S.によ

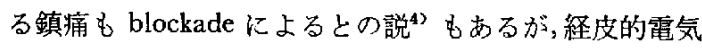
刺激中は加えって患侧肢の温度覚, pin-prick は改善を示 す報告"1があり，末梢に括訬る blockade は根拠がうす い. 最近 opiate recepter cell が脳幹網様織・substantia gelatinosa において見出されているが柿，この関与も十 分可能性が考えられる。

T.E.S.の臨床成績に関しては Long ${ }^{17)} の 400$ 症例の 調查で78\%の慢性痛患者がその恩恵を認めている．さら に継続使用の遠隔調查では，12力月目にアンケートに答 えた104名中, 71名性 T.E.S. のみで鎮痛が得られると しているが，さらに後の調查では 104名中90名が何らか の効果を認めているものの，82名は他の治療法を希望 し，しかもその多くは電気刺激を必要としない治療法を 望んだという．Shealy ${ }^{29)}$ の750例の治験でも，慢性猫に 対しては $25 \%$ 著効，残りの50\%以上は有效で，少なくと る $25 \%$ の患者は T.E.S. 継続療法を望んだとい5，T. E.S. の適応疾患として Long ${ }^{19)}$ は, アメリカの 5 ペイ ン・クリニックより集計した 3,000 例の分析から，一応慢 性痛はすべて対象となりらるが特に末梢神経損傷に由来 する痛み, stump pain, neuroma pain, phantom limb painなどがよい適応とい5。数回の手術を経た chronic back pain は少数例のみ有効, まったく適応外は psychogenic pain, central pain といら.へルペス後神経痛も よい適応 ${ }^{25)}$ であるが，わたくしどもの症例の場合は脱落 している，電極の問題や，高令，説明不足吕原因と考え ている.この他いかゆ五除痛手郝・ブロック後の遗残 痛, 再発痛も一時的には上い適応上なる，偏頭痛症例も 症例によっては適応となるら，刺激部位については痛み 領城の圧痛点や支配神経刺激点, さらに神経叢などを試 みるのであるが， Long は隣接領域の神経刺激む加えて 
いる，これらの点をパラメーターを変えながら刺激する と長時間を要することになり，医師が外来で行らことは 不可能に近く, 訓練されたパラメディカルの人たちが必 要となるう．実際のところは，患者自身がこのテストに 熱中することになる。本療法の欠点は Bates ${ }^{22}$ のT. E.S. 失敗 100 症例の分析で明らかである.彼の症例の半数は最 初のテスト刺激期間て T.E.S. 在拒否，その多くは電気 刺激でおこる感觉と痛みに何の干涉も見られなかったと いら。 その後 1 週閒以上使用し 1 年以内に脱落したもの は，得られる鎮痛効果に較心゙て刺激自体が煩わしい，鎮 痛域より痛みの範围が広い，ある日突然刺激效果がなく なったなり゙の理由を举げている。.Nashold ${ }^{24)}$ は本療法に 関して除痛対策の最初の治療としてまず試みるべきで，

これに上り痛み在訴える患者にも，手術を検討寸る医師 にも，他の適切な方法を考える時間の余裕を与えてくれ ると述べているのは，これらの欠点，限界指摘したも のといえる。これを補らためには莧剤の併用や患者にあ わせた電極の工夫などが必要であ万ら，鎮痛域の㹨さに 対しては，脊㕼後索・中脳中心灰白質・視床特殊核・内 包など中枢に㧍ける電気刺激が秀れていると思われる が，痛みの原因そのものが除去されぬ陙り永続的に刺激 を継続する必要があり，その煩かしさと起こりらる合併 症を考虑すると，や注り痛女の外科の方向としては上り 理想的な手術標的老探求すべきであろうと考える．現状 では各種除痛手術・電気刺激を総合的に駆使して, 碩痛 対策に立ち向から必要がある。

\section{$V$ 要 約}

除痛手術後の遺残痛・再発痛やその他の慢性痛抢よび 悪性腫瘍末期痛など 29 例に対して，国産の携帯用小型 personal stimulator 左用いて，経皮的末梢神経電気刺激

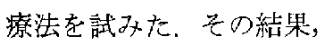

1. テスト刺激では著效上り多少とも効果を認めるも のまで含むと，93\%の患者で有効上なり，たしが鎮痛 効果注認內る.

2. 患者に 1 週間より 2 年10力月にわたる期間 stimulator t貸し出して，患者自身による経皮刺激索継 続し て行わせをもの22例中， $86 \%$ の患者で鎮痛效果を見た，

3. しかし今後も痛みの治療として続けたいとする者 汇 $42 \%$ となった，悪性腫煌末期痛患者全員脱落し，めま い・嘔気などを伴ら頭部外慯後遺症の慢性頭痛患者もほ とんど脱落した。

4. 本療法の実際, 刺激効果, 適応, 限界などにつき 考察した。

5. 各種慢性痛患者に総合的な痛み対策の一つとして
試みてよい方法と考える。

本論文の要旨は第36回日本䏚神経外科学会総会 (1977 年10月，大阪）に掓て発表した。

\section{文献}

1) Adnus, J. E.: Stimulation of internal capsule for relief of chronic pain. $J$ Neurosurg $41: 740-$ 744,1974

2) Bates, J. A. V.: Relief of chronic pain by transcutaneous stimulation. Analysis of 100 consecutive failures (abstract). p 178, In Bonica, J. (ed) : Ist World Congress on Pain, 1975

3) Bloedel, J. R.: The Substrate for Integration in the Central Pain Pathways. Clin Neurosurg 21: 194-228, 1974

4) Campbel., J. N. \& TAub, A.: Local analgesia from percutaneous electrical stimulation. A peripheral mechanism. Arch Neurol 28: 347350, 1973

5) Christensen, B. N. \& Perl, E. R.: Spinal neurons specifically exited by noxious or thermal stimuli: Marginal zone of the dorsal horn. $J$ Neurophysiol 33: 293-307, 1970

6) Ebersold, M. J., Laws, E. R., JR., Stonnington, H. \& Stillwell, G. K.: Transcutaneous Electrical Stimulation for Treatment of Chronic Pain: A Preliminary Report. Surg Neurol 4: 96-99, 1975

7) Fox, J. L.: Dorsal Column Stimulation for Relief of Intractable Pain: Problems Encountered with Neuropacemakers. Surg Neurol 2: 59-64, 1974

8) Higgins, J. D., Tursky, B. \& Schwartz, G. E.: Shock-Elicited Pain and Its Reduction by Concurrent Tactile Stimulation. Science 21: 866-867, 1971

9) Hongo, T., Jankowska, E. \& Lundberg, A.: Postsynaptic exitation and inhibition from primary afferents in neurones in the spinocervical tract. J Physiol 199: 569-592, 1968

10) Hosobuchi, Y.: Chronic thalamic stimulation for the control of facial anesthesia dolorosa. Arch Neurol 29: 158--161, 1973

11) Ignelzi, R. J. \& Sternbach, R. S.: Somatosensory changes during transcutancous electrical analgesia (abstract). p 179, In Bonica, J. (ed): In 1st World Congress on Pain, 1975

12）黑田良太郎 他：ネコにおける三神経脊髄 路核下核上りの上行性経路。 とくに痛覚伝導路 について. 阪大医誌20:103-114，1968

13) Kuroda, R., Murui, H. \& Mogami, H. Some efferent connections of the magnocellular nucleus of medial geniculate body in the cat. 
With special reference to the pain conducting pathways. Med $J$ Osaka Univ $21: 27-46,1970$

14) Kuroda, R., et al.: Some efferent connections of the centromedian nucleus of the cat. Med $J$ Osaka Univ 26: 1-25, 1975

15）众留 勝：人体春蹎並に脑幹に於ける知覚伝 導経路. pp 429-673, 日本学術会議（編）：医学 綜報，第 2 巻，第 4 刪，創元社，東京， 1949

16) LoNG, D. M.: Electrical stimulation for relief of pain from chronic nerve injury. $J$ Neurosurg 39: 718-722, 1973

17) Long, D. M.: Cutaneous Afferent Stimulation for Relief of Chronic Pain. Clin Neurosurg 21: 257-268, 1974

18) Long, D. M. \& HAgFors, N.: Electrical Stimulation in the Nervous System: The Current Status of Electrical Stimulation of the Nervous System for Relief of Pain. Pain 1: 109-123, 1975

19) Long, D. M.: Transcutaneous Electrical Stimulation in the Treatment of Chronic and Acute Pain. pp 54-64, In Lee, J. F. (ed): Pain Management. Williams \& Wilkins Co., Baltimore, 1977

20) Melzack, R. \& Wall, P. D.: Pain Mechanisms: A New Theory. Science 150: 971-979, 1965

21) Melzack, R., Stillwell, D. M. \& Fox, E. J.: Trigger Points and Acupuncture Points for Pain: Correlations and Implications. Pain 3: 3-23, 1977

22) Mumford, J. M.: Influence of Transcutaneous Neural Stimulation on the Pain Threshold of Human Teeth (abstract). p 175, In Bonica, J. (ed): 1st World Congress on Pain, 1975

23) Nashold, B. S., JR. \& Friedman, H.: Dorsal Column Stimulation for Control of Pain. $J$ Neurosurg 36: 590-597, 1972

24) Nashold, B. S., JR.: Electrical Stimulation of the Skin, Peripheral Nerves, or Dorsal Column for Pain Relief. pp 502-509, In Morley, T. P. (ed): Current Gontroversies in Neurosurgery, W. B. Saunders Co., Philadelphia, 1976

25) Nathan, P. W. \& Wall, P. D.: Treatment of Post-Herpetic Neuralgia by Prolonged Electric Stimulation. Br Med J 3: 645-647, 1974

26) Picaza, J. A., et al.: Pain Suppression by Peripheral Nerve Stimulation. Part I Observations with Transcutaneous Stimuli. Surg Neurol 4: 105-114, 1975

27) Satran, R. \& Goldstein, M. N.: Pain Perception: Modification of Threshold of Intolerance and Cortical Potentials by Cutaneous Stimulation. Science 180: 1201-1202, 1973

28) Shealy, C. N., Mortimer, J. T. \& Hagfors, N. R.: Dorsal column electroanalgesia. $J$ Neurosurg 32: 560-564, 1970

29) Shealy, C. N.: Transcutaneous Electrical Stimulation for Control of Pain. Clin Neurosurg 21: 269-277, 1974

30) SNyder, S., et al.: Opiate recepter mechanisms. pp 329-360, In Iverson, L. L. \& Iverson, S. D. (eds): Handbook of Psychopharmacology Vol. 5, Plenum Press, New York, 1975

31) Sweet, W. H. \& Wepsic, J. R.: Treatment of pain by chronic electrical stimulation of large axons. Excep Med Intern Congress Series 198: 81, 1969

32) Wall, P. D. \& Sweet, W. H.: Temporary abolition of pain in man. Science 155: 108-109, 1967

33) WaLI, P. D.: Dorsal Horn Electrophysiology. pp 253-270, In Iggo, A. (cd): Handbook of Sensory Physiology, Vol, II, Springer-Verlag, Berlin, 1973

34) WALL, P. D.: Physiological mechanisms involved in the production and relief of pain. $\mathrm{Pp}$ 36-63, In Bonica, J. J., Procacci, P. \& Pagni, C. A. (cds): Recent Advances on Pain. Pathophysiology and Clinical Aspects. C. C. Thomas, Springfield, 1974 